\title{
Tanggung Jawab Perusahaan Transnasional terhadap Pelanggaran HAM dalam Perspektif Hukum Internasional
}

\author{
Sefriani \\ Universitas Islam Indonesia, Yogyakarta
}

\begin{abstract}
Recognition of Transnational Enterprises (TNEs) as subjects of international law is unclear, and therefore, their responsibilities are also ambiguous. As a consequence, various violations of human rights committed by the TNEs in some developing and least-developed countries, both in the era of World War II and in the era of globalization were left enforceable. Recently, there are some international law instruments imposing obligation directly on the TNEs. Despite being soft laws and having some weaknesses, these instruments can be considered as the international customary laws, having legal binding upon all nations. This article argues that it is urgent to establish a new system of TNEs responsibility, and to learn and compare between individual and state responsibility systems in human rights violations. This is because TNEs are entities that are more than individual persons but less than the State.
\end{abstract}

Keywords: Human rights violation, responsibility, TNEs.

Kehadiran perusahaan transnasional ${ }^{1}$, Mperusahaan yang mengendalikan perusahaan dari suatu negara tetapi meluaskan operasionalnya di berbagai negara lain bukanlah hal yang asing, terlebih diera globalisasi saat ini. Kehadiran perusahaan-perusahaan tersebut sampai saat ini diperebutkan oleh negara-negara khususnya negara berkembang (developing countries) dan negara terbelakang (least developing countries). Masing-masing negara berlomba-lomba mempercantik diri dengan memberikan berbagai kemudahan dan fasilitas agar investor asing tertarik menanamkan modal di negaranya.
Suatu negara yang mengundang masuk investor asing dengan perusahaanperusahaan transnasionalnya berharap bahwa perusahaan-perusahaan tersebut dapat menjadi agent of development (Sumantoro, 1984). Dengan modal dan teknologi yang mereka miliki diharapkan perusahaan-perusahaan tersebut dapat mengelola sumber daya alam yang ada di negara tuan rumah (host state), meratakan pembangunan, meningkatkan ekspor, meningkatkan pemasukan pajak, membuka

\footnotetext{
${ }^{1}$ Untuk selanjutnya akan disingkat dengan TNC (Transnasional Corporation)
} 
Tanggung Jawab Perusahaan Transnasional terhadap Pelanggaran...; Sefriani

lapangan pekerjaan, memberikan teknologiteknologi baru serta meningkatkan kualitas SDM host state.

Namun demikian, pada kenyataannya seringkali kehadiran perusahaan-perusahaan transnasional tersebut justru menimbulkan berbagai masalah serius bagi host state. Salah satu masalah serius yang dimaksud adalah terjadinya pelanggaran HAM terhadap penduduk lokal (Todung, 2004). Beberapa kasus nyata pelanggaran HAM oleh TNC yang dapat dikemukakan antara lain adalah yang dilakukan perusahaan minyak Shell di Nigeria. Perusahaan minyak ini dalam mengeks-ploitasi minyak di kawasan Ogoniland telah mengabaikan dan melanggar hak-hak kesehatan, lingkungan, hak-hak akan makanan, dan hak komunitas lokal yang berakibat pada rusaknya sendi-sendi kehidupan di Ogoniland (Todung, 2004). Kasus lain adalah Unocal Incorporation yang bersama-sama dengan Myanmar Oil Gas Enterprise di Myanmar diduga melakukan kerja paksa dan eksploitasiburuh anak, serta memaksa penduduk lokal untuk pindah (Todung, 2004). Selanjutnya, kasus terbakarnya pabrik mainan Zhili di Shenzhen pada tahun 1993. Kebakaran ini menewaskan 87 pekerja serta melukai 47 lainnya pada tahun 1993. Pabrik yang memproduksi mainan "Chicco" itu ternyata tidak dilengkapi alat pemadam kebakaran dan tertutup. Dalam kasus ini tidak ada kompensasi bagi keluarga pekerja yang tewas. Yang luka bakar pun tidak mendapat pengobatan yang memadai ${ }^{2}$. Hal ini terulang pada tahun 1994 di Zuhai, yang menewaskan 93 orang dan 49 lainnya mengalami luka bakar serius. Tahun 1995, di Shunda, 32 orang tewas. Sebagian besar adalah perempuan muda dari pedesaan. Di pabrik pemasok mainan McDonald di Zuhai pernah terjadi keracunan benzene, Tragedi serupa juga terjadi di banyak negara berkembang lainnya.

Adapun kasus yang terjadi di Indonesia antara lain kasus pelanggaran HAM oleh PT Freeport.di Papua serta Exxon Mobile di Aceh. Kedua perusahaan ini diduga telah mengucurkan dana yang cukup besar pada aparat keamanan Indonesia untuk meniadakan gangguan dan menjaga fasilitas produksi mereka (Francois, 1991). Exxon Mobile menyediakan dana juga fasilitas gedung yang digunakan aparat Indonesia untuk melakukan kekerasan, pembunuhan massal, pemerkosaan, penyiksaan, penghilangan secara paksa terhadap penduduk lokal yang dicurigai bekerjasama dengan GAM mengganggu kegiatan perusahaan tersebut.

Meskipun dalam praktek sudah banyak dibuktikan adanya pelanggaran HAM yang dilakukan berbagai perusahaan transnasional namun pada umumnya hanya sedikit yang bisa ditindaklanjuti atau diproses secara hukum. Pada umumnya penduduk lokal yang dirugikan tidak dapat menuntut perusahaan-perusahaan transnasional tersebut di pengadilan nasional mereka karena perusahaan-perusahaan raksasa tersebut senantiasa dilindungi oleh pemerintah host state. Perusahaanperusahaan tersebut dapat terus beroperasi bahkan memperpanjang kontraknya dengan pemerintah setempat (Advokasi, 2005).

Bilamana di lingkup pengadilan nasional host state cukup sulit untuk meminta pertanggungjawaban perusahaan transnasional atas pelanggaran HAM yang

${ }^{2}$ Kasus ini merupakan kesaksian seorang peneliti muda dari Hongkong dikemukakan pada Pertemuan internasional mengenai HAM Buruh dalam Peoples Summit mengenai APEC di Vancouver, Kanada, November 1997, Kompas, tanggal 16 Januari 2004 
dilakukannya maka demikian pula halnya dilingkup internasional. Doktrin hukum internasional klasik pada umumnya hanya menempatkan negara sebagai subyek hukum internasional. Aturan-aturan tentang HAM pada umumnya ditujukan pada negara dan aparat negara (state agent), (David, 2002) bukan pada perusahaan transnasional. Hal ini tidak lepas dari kenyataan bahwa dalam hukum internasional perusahaan transnasional belumlah dipandang sebagai subyek hukum yang sesungguhnya ${ }^{3}$. Francois Rigaux misalnya berpendapat bahwa....it must be emphasized that transnasional corporations are neiher subjects nor quasisubjects of international law"(Francois, 1991). Untuk menuntut maupun dituntut di pengadilan internasional ia masih harus diwakili oleh negaranya. Mahkamah Internasional (International Court of Justice) misalnya hanya bisa mengadili negara. Adapun Pengadilan Pidana Internasional (International Criminal Court) yurisdiksinya terbatas pada individu yang melakukan kejahatan perang, kejahatan kemanusiaan, genocide dan agresi (Statuta Roma, 1998).

Doktrin Hukum internasional klasik sebagaimana dikemukakan di atas tentunya sudah sangat tidak mencukupi kebutuhan dewasa ini. Dalam perkembangannya baik ditingkat regional maupun internasional telah ada upaya membuat instrumen-instrumen hukum yang mengatur langsung hak dan kewajiban perusahaan transnasional. Dengan adanya instrumen yang membebani hak dan kewajiban langsung pada TNC menurut Carlos M Vazquez, maka TNC tersebut potensial untuk ditundukkan pada tindakan penegakan hukum (enforcement action) oleh lembaga-lembaga internasional. Berbeda halnya bilamana instrumen yang ada tidak mengaturnya secara langsung maka TNC tersebut hanya tunduk pada hukum domestik negara dimana ia menjalankan operasinya (host state) serta dalam beberapa hal tunduk pada negara dimana ia didirikan (home state) (Carlos, 2005). Bagaimana bentuk-bentuk pelang-garan HAM Perusahaan Transnasional, bagaimana hukum internasional mengatur mengenai tanggung jawab perusahaan transnasional atas pelanggaran HAM tersebut serta bagaimana pula praktek pertanggungjawaban pelanggaran HAM TNC tersebut akan diulas dalam tulisan berikut.

\section{Bentuk-bentuk Pelanggaran HAM Perusahaan Transnasional}

Berdasarkan temuan pelanggaran HAM oleh perusahaan transnasional di lapangan, Universitas Hardvard telah melakukan pengkategorian pelanggaran HAM yang dilakukan perusahaan transnasional. Pengkategorian ini lebih menekankan pada ruang lingkup atau jenis pelanggaran HAM . Pengkateorian yang dimaksud sebagaimana dimuat dalam Harvard Law Review adalah sebagai berikut (Harvard, 2001):

a. Pelanggaran terhadap hak-hak ekonomi, sosial dan budaya. Dapat dicontohkan misalnya pelanggaran terhadap the enjoyment of just and

\footnotetext{
${ }^{3}$ Banyak penulis hukum internasional seperti Starke, Mochtar Kusumaatmadja, I Wayan Parthiana, tidak memasukkan perusahaan transnasional sebagai subyek hukum internasional. Subyek hukum internasional menurut mereka adalah negara, organisasi internasional, individu, vatican, ICRC, belligerent, serta oranisasi pembebasan nasional/ bangsa yang memperjuangkan haknya. Lihat lebih lanjut dalam ! Wayan Parthiana, 1990, Pengantar Hukum Internasional, Mandar Maju, Bandung, hlm. 5893, Mochtar Kusumaatmadja, Pengantar Hukum Internasional, Buku I Bagian Umum, Binacpta, Jakarta, catakan keempat, 1982
} 
Tanggung Jawab Perusahaan Transnasional terhadap Pelanggaran...; Sefriani

favourable conditions of work" misalnya: fair wages and equal remuneration for work of equal value", "safe and healthy working conditions", pay exceedingly low wages, use forced labor, atau force employees to work under hazardous conditions without adequate safeguards. Perusahaan yang membuang limbah beracun ke sungai dan menyebabkan pencemaran secara luas dikatakan melanggar the right "to the enjoyment of the highest attainable standard of physical and mental health." Demikian halnya perusahaan yang merusak habitat penduduk asli adalah melanggar, the right of all peoples to "freely pursue their economic, social and cultural development," including the right not to be deprived of their own means of subsistence

b. Pelanggaran hak-hak sipil dan politik. Dalam kasus Wiwa v. Royal Dutch Petroleum Co. penggugat menuduh Royal Dutch/Shell telah menggunakan militer Nigeria untuk menekan kelompok oposisi yang menentang eksplorasi minyak perusahaan tersebut di Nigeria. Perusahaan memberikan uang, senjata dan logistik pada militer untuk menangkap, memenjarakan dna menyiksa aktivis Nigeria yang vokal. Perusahaan telah melanggar rights to life, freedom from torture, freedom from arbitrary arrest and detention, juga hak untuk mendapatkan a fair trial.

c. Pelanggaran terhadap hak-hak yang dilindungi oleh hukum humaniter internasional. Pelanggaran yang dimaksud adalah genocide, crimes against humanity, and war crimes, yang secara umum terjadi dalam konteks kekerasan massal dan sistematis. Sebagai contoh pelanggaran terhadap ketentuan larangan memproduksi senjata yang dilarang oleh hukum humaniter internasional seperti biological weapons, untuk menyerang tentara musuh dan penduduk sipil. Pelanggaran lain yang dilaukan perusahaan seperti memperkerjakan slave labor di pabrik-pabrik mereka saat perang. Perusahaan juga sering melibatkan diri mereka sendiri dalam war crime. Perusahaan-perusahaan keuangan khususnya banyak berpartisipasi dalam a state's "plunder of public or private property" dengan cara melakukan pencucian uang atau prosesproses semacam itu.

Bilamana Universitas Harvard mendasarkan pada ruang lingkup atau jenis pelanggaran HAM, maka beberapa pakar hukum internasional maupun HAM juga lembaga-lembaga internasional membuat pengkategorian berdasarkan cara maupun tingkat keterlibatan perusahaan transnasional terhadap pelanggaran HAM yang terjadi. Surya Deva misalnya, mengemukakan bahwa dalam praktek, pelanggaran-pelanggaran HAM yang dilakukan perusahaan transnasional dapat terjadi dalam berbagai macam cara seperti directly violating human rights, assisting in violations, failing to prevent violations, remaining silent about violations, or even operating in a state that violates human rights. Adapun Anita Ramasastri seorang peneliti dari Myanmar (Birma) mengemukakan bahwa Pelanggaran HAM yang dilakukan perusahaan transnasional dapat dibedakan dalam dua bentuk yaitu (Anita, 2002):

a. Pelanggaran HAM yang melibatkan perusahaan secara langsung (direct complicity).

b. Pelanggaran HAM yang melibatkan perusahaan secara tidak langsung (indirect complicity).

Perusahaan dikatakan terlibat secara 
langsung dalam suatu pelanggaran HAM manakala perusahaan "decides to participate through assistance in the commission of human rights abuses and that assistance contributes to the commission of the human rights abuses by another." Dalam keterlibatan langsung ini tidak diperlukan syarat bahwa hasil kejahatan diinginkan oleh perusahaan tetapi cukup bahwa seharusnya perusahaan mengetahui akibat yang mungkin muncul dari bantuan yang ia berikan . Perusahaan-perusahaan Jepang dan Jerman yang menggunakan forced labor selama perang Dunia II masuk kategori terlibat secara langsung dalam pelanggaran HAM . Dalam banyak kasus perusahaaanperusahaan tersebut mencari atau menyetujui pemanfaatan tenaga kerja paksa untuk melancarkan operasional bisnis mereka serta mengetahui konsekwensi dari apa yang mereka lakukan.

Keterlibatan perusahaan secara tidak langsung (indirect corporate complicity) sering juga disebut dengan keterlibatan untuk memperoleh keuntungan (beneficiary corporate complicity). Dalam kategori ini bukanlah perusahaan yang melakukan sendiri secara langsung kejahatan internasional yang dimaksud (perperator), tetapi perusahaan memperoleh keuntungan dari pelanggaran HAM yang dilakukan oleh negara tuan rumah (host state). Masuk kategori ini umumnya adalah perusahaanperusahaan yang memiliki kontrak kerjasama (partnership or joint ventures) dengan pemerintah tuan rumah (host government) dan bahwa pelanggaran HAM yang dilakukan dalam rangka proyek-proyek tertentu yang merupakan kerjasama perusahaan dengan pemerintah tuan rumah. Contoh yang banyak ditemukan dalam praktek adalah penggunaan aparat militer tuan rumah untuk menjaga fasilitas -fasilitas milik perusahaan juga untuk melakukan tindakan- tindakan represif terhadap para demonstran yang memprotes aktifitas perusahaan. Hubungan antara Unocal dengan pemerintah Mynmar dalam pembangunan pipa minyak yang mendapat protes warga setempat adalah contoh kasus keterlibatan secara tidak langsung perusahaan .

Pengkategorian lain juga dilakukan oleh Steven R Ratner dalam artikelnya yang berjudul Corporations and Human Rights: a Theory of Legal Responsibility. Dalam tulisannya ini, Ratner mengemukakan bahwa kedekatan hubungan antara perusahaan dengan pemerintah dapat dijadikan faktor penentu pertanggung-jawaban perusahaan. Lebih lanjut Ratner mengemukakan bahwa perusahaan dapat bertindak selaku government agent, complicit with government serta bertindak selaku commander.

Tidak jauh berbeda dengan pengkategorian-pengkategorian sebelumnya, secara rinci International Council on Human Rights Policy yang bermarkas di Swiss, menemukan adanya empat kondisi keterlibatan perusahaan transnasional dalam suatu pelanggaran HAM yang terjadi di suatu negara. Empat kondisi tersebut antara lain, pertama adalah Perusahan aktif membantu (active participation) Kedua Joint Venture .. Ketiga adalah kondisi dimana Perusahaan memperoleh keuntungan dari kondisi yang tercipta akibat pelanggaran HAM, bahkan meskipun perusahan tidak memberikan bantuan pada perpetrator. Keempat menurut International Council on Human Rights Policy adalah Perusahaan silent/inactive dalam menghadapi pelanggaran HAM. Pada kondisi keempat ini, Perusahaan menyadari terjadinya pelanggaran HAM, tetapi tidak berusaha mencegah atau menghentikannya. Sebagai contoh dapat dikemukakan misalnya perusahaan 
Tanggung Jawab Perusahaan Transnasional terhadap Pelanggaran...; Sefriani

yang tidak betindak ketika pekerjanya ditangkap sewenang-wenang oleh pemerintah, atau perusahaan mene-rima dan menerapkan perlakuan diskriminasi sistematis dari pemerintah terhadap kelompok kerja tertentu berdasarkan etnis, gender atau warna kulit. Hukum pidana pada umumnya lebih menekankan sanksi untuk action daripada omission atau inaction seperti tindakan diam terhadap terjadinya ketidakadilan. Meskipun demikian tidak berarti bahwa sistem hukum pidana tidak mengenal tanggung jawab untuk inaction. Silence tidaklah selalu netral dan dapat dimasukkan menjadi tindakan aktif membantu. Seorang penonton kejahatan dapat didakwa aiding and abetting jika statusnya atau keberadaannya justru menjadi dukungan bagi pelaku untukmelakukan pelanggaran HAM. Kehadiran perusahaan transnasional yang memiliki kedekatan politik dengan penguasa atau memiliki kekuatan ekonomi tertentu dapat menjadi pendorong bagi host state untuk melakukan pelanggaran HAM Dalam sistem civil law kewajiban untuk menyelamatkan orang-orang yang dalam bahaya menjadi sangat relevan diterapkan pada perusahaan yang tidak melakukan tindakan apapun untuk mencegah penderitaan orangorang yang seharusnya dibawah perlindungannya. Majikan mempunyai kewajiban khusus melindungi pekerjanya dari kejahatan atau kerugian (harm), Pemilik restoran atau hotel memiliki kewajiban yang sama terhadap langgannya, demikian halnya staf rumah sakit terhadap para pasien. Dengan demikian, perusahaan memiliki kewajiban melindungi para pekerjanya dari pelanggaran HAM yang dilakukan pemerintah termasuk di dalamnya misalnya penangkapan atau pemenjaraan yang sewenang-wenang. Ketika perusahaan transnasional memperoleh keuntungan ekonomi, misalnya dari penduduk lokal yang dilanggar HAM-nya oleh pemerintah, yang memindahkan secara paksa mereka dari habitatnya yang kemudian akan dijadikan jalan atau hotel atau proyek tertentu, perusahaan memiliki kewajiban untuk mengambil tindakan-tindakan pencegahan terjadinya kerugian (injury). Dalam English Tort Law ditegaskan bahwa seseorang diwajibakan mengontrol pihak lain yang dengannya ia memiliki hubungan khusus, bila ia memiliki right of control atas pihak tersebut. Perusahaan transnasional yang pada umumnya membuat kontrak kerjasama dengan pemerintah memiliki hak serta kewajiban mengontrol tindakan pemerintah terlebih tindakan-tindakan kekerasan. Tidak berbuatnya perusahaan transnaisonal dalam kaitannyan dengan korban dan pemerintah yang diluar lingkup pengaruhnya (sphere of influence) tidak dapat dikenakan sanksi baik dalam secara perdata maupupu pidana.Dengan kata lain sekedar kehadiran di suatu negara yang di dalamnya terjadi pelanggaran HAM tetapi tidak ditemukan faktor perolehan keuntungan maupun partisipasi secara langsung maupun tidak langsung tentu saja tidak menimbulkan adanya pertang-gungjawaban dari perusahaan transnasional tersebut.

Demikianlah dari paparan di atas dapat disimpulkan bahwa pada dasarnya pelanggaran HAM oleh TNC dapat dibedakan menjadi pelanggaran HAM yang dilakukan oleh TNC itu sendiri secara langsung maupun secara tidak langsung. Termasuk kategori pertama adalah TNC bertindak selaku perpetratornya. TNC melalui aparataparat yang dimilikinya (enterprise civil security) melakukan pelanggaran HAM atas dasar kebijakan TNC itu sendiri maupun sekedar melaksanakan perintah negara (as agent of government). Termasuk kategori pelanggaran HAM secara tidak langsung adalah kondisi dimana TNC bukan sebagai 
UNISIA, Vol. XXX No. 65 September 2007

eksekutor atau per-petratornya, tetapi TNC hanya sekedar memberikan persetujuan, fasilitas,dukungan ataupun bersifat pasif, tidak berupaya memberikan perlindungan terhadap korban ataupun tidak berupaya melakuakn pencegahan terjadinya pelanggaran HAM yang nyata-nyata diketahui olehnya danTNC mendapatkan keuntungan dari pelanggaran HAM yang dilakukan oleh pihak lain tersebut. Masuk kategori ini juga adalah TNC sebagai commander, dengan pengaruh dan kekuatan yang dimilikinya TNC memberikan perintah dan fasilitis pada aparat pemerintah untuk melakukan pelanggaran HAM demi kelangsungan bisnisnya di negara tersebut.

\section{Primary rules: Pelanggaran HAM Perusahaan Transnasional}

Pengaruh H.I klasik yang menempatkan bahwa hanya negara yang merupakan subyek, penyandang hak dan kewajiban dalam H.I masih sangat mendominasi primary rules hukum internasional, khususnya yang berkaitan dengan HAM saat ini. Beberapa contoh primary rules yang memberikan kewajiban langsung pada negara antara lain nampak pada Pasal 28 Universal Declaration of Human Right (UDHR), Pasal 2(1) International Covenant on Civil and Political Right (ICCPR), serta Pasal 2(1) International Covenant on Economic, Social and Cultural Right (ICESCR) yang mewajibkan negara peserta untuk ... respect and to ensure to all individuals within itsssss territory and subjects to its jurisdiction the rights recognized in the present covenant Kata respect mengandung negative obligation yaitu melarang langsung negara melakukan pelanggaran HAM. Adapun kata ensure berimpilikasi pada keharusan negara untuk mengambil langkah-langkah positif untuk menjamin dilaksanakannuya penghormatan HAM melalui tindakan legislasi maupun tindakan-tindakan yang lain. Negara wajib melindungi individu dari gangguan hak-hak sipil dan politik mereka yang dilakukan oleh pihak-pihak lain, kelompok ataupun entitas (Engstrom, 2002).

Contoh yang lain yang juga memberikan kewajiban langsung pada negara adalah The UN Convention on the Elimination of All Forms of Discrimination against woman yang mewajibkan negara untuk mengambil semua tindakan yang tepat untuk menghapuskan diskriminasi terhadap wnaita oleh individu yang lain, organisasi atau perusahaan. Demikian halnya dengan The UN Convention on the Elimination of All Forms of Racial Discrimination (CERD) yang dalam Pasal 2(1) -nya mewajibkan negara untuk prohibit and bring to and end...racial discrimination by any person, group, or organization.

Akibat hukum dari pengaturan yang ditujukan langsung pada negara sebagaimana contoh-contoh di atas adalah bahwa hanya negara yang dapat dimintai pertanggungan jawab terhadap pelanggaranpelanggaran kewajiban yang diamanatkan oleh instrumen-intrumen yang merupakan primary rules hukum internasional tersebut. Konstitusi banyak negara seperti halnya Inggris misalnya menetapkan bahwa... the treaty has no effeect on private parties until implemented by the legislature. Non state actor yang melakukan diskriminasi rasial tidaklah melanggar CERD. Negaralah yang melanggar treaty tersebut dengan kegagalannya to prohibit and take other steps to eradicate such discrimination yang diwajibkan CERD. Meskipun berbagai primary rules tersebut juga membebani kewajiban pada non state actor untuk menghormati HAM tetapi bukan mereka langsung yang dibebani kewajiban hukum internasional. Dengan kata lain dapat dikatakan bahwa berbagai intrumen H.I 
Tanggung Jawab Perusahaan Transnasional terhadap Pelanggaran...; Sefriani

tersebut hanya membebani kewajiban tidak langsung pada non state actor untuk menghormati HAM.

Perbedaan antara pembebanan secara langsung dengan yang tidak langsung terhadap kewajiban hukum internasional menurut Carloz adalah bahwa jika H.I hanya memberikan kewajiban tidak langsung (indirectly obligation) pada non state actor termasuk di dalamnya perusahaan transnasional maka mereka hanya tunduk pada hukum nasional dimana mereka melakukan pelanggaran. Tetapi bilamana H.I memberikan kewajiban langsung pada mereka maka mereka berpontensial ditundukkan pada enforcement action oleh lembagalembaga internasional.

Mekanisme internasional sebagaimana dikemukakan di atas yang hanya membebani kewajiban tidak langsung pada perusahaan transnasional terbukti gagal karena memiliki banyak kelemahan.: Kelemahan pertama menurut Surya Deva adalah bahwa. negara tidak dapat melaksanakan kontrol secara efektif pada perusahaan transnasional karena keterbatasan yurisdiksinya (transborder limitation). Negara memiliki definite territory adapun perusahaan transnasional tidak (Jonathan, 1983). Kelemahan kedua menurut Surya Deva timbul karena kadang-kadang negara atau perusahaannya bekerjasama dengan perusahaan transnasional untuk keuntungan masing-masing sehingga pelanggaran HAM yang dilakukan perusahaan transnasional juga mengun-tungkan negara. Kelemahan ketiga, untuk menarik investasi asing negara sering tidak memperdulikan penegakan norma-norma HAM bahkan memberikan standar yang sangat rendah untuk penegakannya. Keempat, meskipun negara ada kemauan untuk mengontrol perusahaan transnasional di wilayahnya, namun seringkali negara tidak memiliki legal and or economic capacity untuk melakukannya. Hal ini dikarenakan di banyak negara khususnya negara berkembang dan terkebelakang, perusahaan transnasional merupakan powerful global actor. Kekuatan atau kemampuan negara dalam segala hal kalah dibandingkan perusahaan-perusahaan tersebut. Kelima, karena perusahaan transnasional beroperasi di banyak negara, seringkali tuntutan pertanggungjawaban di depan pengadilan ansional dikandaskan oleh prinsip forum non convenience. Keenam, kekhawatiran adanya konflik antara host state dengan home state perusahaan transnasional bilamana hukum nasional dari negara $X$ misalnya diterapkan terhadap perusahaan yang berasal dari negara Y.Ketujuh, negara seringkali tidak konsisten dalam penghormatan dan penegakan HAM internasional.

Kegagalan instrumen-instrumen $\mathrm{H} . \mathrm{I}$ dengan sistem indirectly obligation bagi perusahaan transnasional menjadikan latar belakang dibuatnya instrumen-instrumen atau primary rules dengan sistem directly obligation.Sistem kedua ini memberikan kewajiban langsung pada perusahaan transnasional untuk menghormati HAM . Tercatat sebagaimana dipaparkan pada BAB II antara lain OECD Guidelines, ILO Tripartite Declaration, Global Compact, juga Norms on The Responsibilities of Transnational Corporations and Other Business Enterprises with Regard to Human Rights, U.N. Doc. E/CN.4/Sub.2/2003/38/Rev.2 (2003).

Meskipun hukum internasional telah melakukan perubahan sistem yaitu dengan membebani kewajiban langsung pada perusahaan transnasional, namun sampai saat dapat dismpulkan bahwa mayoritas instrumen-instrumen tersebut masih banyak memiliki kelemahan sebagaimana berikut ini:

a. Tidak adanya konsensus standar 
UNISIA, Vol. XXX No. 65 September 2007

pelanggaran HAM

b. HAM untuk keuntungan bisnis

c. Terlalu berlebihannya dialog dan kerjasama

d. Pendekatan Tidak langsung

e. Kurangnya sanksi .

Terlepas dari segala kelemahan yang terkandung dalam instrumen-instrumen primary rules ini, yang dipandang belum cukup memadai yaitu dalam hal keberadaan standar HAM (kelemahan pertama), dalam hal dasar pemikran atau prinsip-prinsip yang mendasarinya (kelemahan kedua dan ketiga), dalam hal struktur atau sistem pertanggungjawabannya (kelemahan keempat) serta dalam hal implementasinya (kelemahan kelima), namun setidaknya, instrumen-instrumen tersebut yang merupakan soft law telah memberikan pengaruh pada proses perubahan hukum internasional atau progressive development of international law. Melalui instrumen soft law tersebut akan dapat terbentuk hukum kebiasaan internasional yang mengikat serta dapat mendukung terbentuknya kaedah baru hukum internasional yang mengikat untuk menerapkan akuntabilitas pada perusahaan transnasional atas pelanggran HAM mereka.

\section{Praktek Pertanggungjawaban Pelanggaran HAM TNC}

Di lingkup pengadilan internasional sebenarnya memang telah dilakukan proses peradilan yang menyangkut pelanggaran HAM oleh perusahaan transnasional. Sayang sekali keterbatasan yurisdiksi yang diberikan pada pengadilan-pengadilan tersebut menjadikan baru pimpinanpimpinan perusahaan saja yang dimintai pertanggungjawaban atas apa yang telah dilakukan oleh perusahaannya. Disamping itu., jenis pelanggaran HAM yang dapat diajukan ke pengadilan internasional barulah terbatas pada pelanggaran yang dilindungi oleh Hukum Humaniter Internasional yang mencakup kejahatan-kejahatan internasional (internaisonal crime) yang merupakan musuh seluruh bangsa, seperti genocida, cimes against humanity, war crime, juga slavery (Harvard, 2001).

Ada beberapa kasus menyangkut perusahaan transnasional Jerman dan Jepang di pengadilan militer internasional pascaPerang Dunia II. Kasus Farben merupakan kasus pertama pengadilan internasional menerapkan pertanggungjawaban (liability) terhadap sekelompok orang yang secara kolektif berada dalam satu perusahaan atas kejahatan yang mereka lakukan yaitu use of slave labor. Hal yang menarik untuk dicatat dalam kasus Farben adalah bahwa pengadilan menyatakan bahwa dirinya tidak memiliki yurisdiksi terhadap legal person dan karenanya dakwaan maupun putusan tidak ditujukan pada perusahaan. Meskipun demikian putusan pengadilan secara jelas menunjukkan sifat perusahaan dan perannya dalam pelaksanaan kejahatan-kejahatan tertentu. Farben digambarkan sebagai instrumen yang digunakan para aktor individual untuk kejahatan secara kolektif..Farben sebagai institusi tidak diletakkan dibawah dakwaan melakukan kejahatan, ia bukanlah subyek tuntutan. Pengadilan menyatakan bahwa para tertuduh individual secara kolektif menggunakan institusi Fraben sebagai instrumen melakukan sejumlah kejahatan yang didakwakan Pengadilan juga mencatat bahwa Farben sebagai suatu corporate entity, terlibat secara langsung dalam war crimes dan crimes against humanity. Sebagai contoh menurut pengadilan adalah bahwa ....Auschwitz was financed and owned by Farben . . . The Auschwitz construction workers furnished by the concentration 
Tanggung Jawab Perusahaan Transnasional terhadap Pelanggaran...; Sefriani

camp lived and labored under the shadow of extermination ...."

Penganalogian perusahaan dengan individual person merupakan merupakan sesuatu yang dinilai paling memuaskan dari putusan pengadilan. Penganalogian itu adalah sebagai berikut::

Where private individuals, including juristic persons, proceed to exploit the military occupancy by acquiring private property against the will and consent of the former owner, such action not being expressly justified by any applicable provision of the Hague Regulations, is in violation of international law. The payment of a price of other adequate consideration does not, under such circumstances, relieve the act of its unlawful character. Similarly, where a private individual or a juristic person becomes a party to unlawful confiscation of public or private property by planning and executing a well-defined design to acquire such property permanently, acquisition under such circumstances subsequent to the confiscation constitutes conduct in violation of the Hague Regulations.

Kasus berikutnya adalah kasus The Krupp Firm. Sama dengan Fraben pengadilan juga menuntut 12 orang dari The Krupp untuk keterlibatan ( commission) mereka dalam war crimes dan crimes against humanity yaitu plunder and spoliation of civilian property and factories in occupied territories, juga deportasi dan penggunaan tawanan perang tenaga kerja paksa dicamp -camp milik perusahaan Krupp di Jerman. Dalam kasus ini, pengadilan menyimpulkan bahwa perusahaan melakukan "Deportation, Exploitation and Abuse of Slave Labor". The Krupp firm berpartisipasi intensif dalam program kerja paksa pemerintah. Perusahaan memanfaatkan tawanan perang, warga sipil asing dan kamp konsentrasi untuk dipekerjakan di pabrik-pabarik the Krupp. Akhirnya, perusahaan menyatakan bahwa the Krupp firm planned, desired, and sought forced labor, or engaged in plunder and pillage, exemplifies the way in which (1) some criminal acts are the manifestation of planning and execution at the firm level, and (2) courts can attribute liability to the MNC as well as its employees.

Kasus berikutnya adalah kasus Karl Rasche, pimpinan Dresdner Bank, sebuah bank swasta di Jerman. Rasche diadili berdasarkan the Nuremberg Charter. la dituduh memfasilitasi slave labor dengan cara meminjami hutang pada entitas yang melakukan slave labor. Pada hukum internasional modern apa yang dilakukan Rasch dapat dianalogikan dengan liability of individuals and legal persons for money laundering or for financing terrorist activity as situations in which the knowing provision of financial assistance contributes to criminal conduct and also triggers liability for the financial activities

Disamping perusahaan-perusahaan Jerman, perusahaan-perusahaan Jepangpun juga diajukan ke depan pengadilan militer antara lain dalam kasus Japanese Mining Company Officials and the Kinkaseki Mine Peradilan terhadap Kinkaseki Mine dilakukan di depan the British War Crimes Court di Hong Kong Mei 1947. Pada kasus ini pengadilan dihadapkan pada persoalan apakah perusahaan dapat dimintai pertanggungjawaban terhadap perlakuan buruk pada tawanan perang yang dipekerjakan paksa di perusahaan tambang di Formosa.

Kondisi saat perang Dunia ke II memang berbeda dengan kondisi saat ini, perusahaan sering berada di bawah tekanan pihak militer, meskipun demikian sebagaimana telah dipaparkan sebelumnya, pengadilan militer terhadap perusahaan- 
UNISIA, Vol. XXX No. 65 September 2007

perusahaan tersebut telah sedikit memberikan parameter kapan suatu perusahaan dapat dimintai pertang-gungjawaban berkaitan dengan pelanggaran HAM yang dilakukannya secara langsung maupun tidak langsung. Dengan demikian permasalahannya bukan lagi pada apakah perusahaan transnasional dapat dimintai pertanggungjawaban atau tidak namun pada kondisi seperti apa perusahaan transnasional dapat dimintai pertanggungan jawab.

Dewasa ini argumen pembelaan TNC bahwa apa yang dilakukannya atas permintaan tuan rumah adalah tidak relevan karena TNC berkolaborasi dengan repressive governments. TNC tidak dalam kondisi perang dan TNC mempunyai kebebasan menentukan apakah ia mau berkolaborasi dengan pemerintah tuan rumah atau tidak.

Kasus tuntutan terhadap Nippon Mining, Farben, Krupp, dan Rasche memberikan kita gambaran dapat dikenakannya Culpability bagi perusa-haan.Di satu sisi partisipassi aktif merupakan dasar yang cukup menerapkan tanggungjawab pidana (criminal liability). Di sisi lain tindakan yang hanya menyediakan uang untuk pembangunan kamp konsentrasi (consentration camp) belumlah cukup. Dewasa ini peradilan kasus Rwanda dan Yugoslavia memberikan preseden bahwa mengetahui dilakukannya kejahatan perang atau kejahatan kemanusiaan sudah cukup menimbulkan, accomplice liability. Dalam kasus Rasche adanya hubungan bisnis yang berkelanjutan dimana akan melahirkan suatu pertanggungjawaban pidana.Masalah TNC culpability seharusnya menimbulkan adanya batasan tentang level, degree and duration of complicity, and the context in which that complicity occurs. Sekali memberikan pinjaman misalnya tidaklah mencetuskan pertanggungjawaban adapun bisnis yang berkelanjutan dapat melahirkan pertanggungjawaban Putusan USMT memang dalam kondisi peperangan adapun pelanggaran HAM yang dilakukan banyak TNC saat ini di luar konteks tersebut. TNC yang bekerjasama dengan repressive government dinilai merupakan kasus yang lebih kuat melahirkan suatu pertanggungjawaban. Meskipun demikian putusan-putusan pengadilan militer tesebut kiranya dapat memberikan petunjuk pada saat terjadinya internal civil conflicts.

Pembentukan Pengadilan-pengadilan kejahatan perang sudah memberikan preseden dapat dilakukan akuntabilitas terhadap private civilian untuk pelanggaran hukum humaniter internasional yang dilakukannya. Pengadilan-pengadilan tersebut seperti halnya pengadilan untuk Jerman dan Jepang juga memberikan parameter kapan dapat dialihkannya pertanggungjawaban pada legal person dan private actor berkaitan dengan pelanggaran HAM berat seperti perbudakan meskipun diakui bahwa kedua pengadilan tersebut masih lebih memfokuskan pada individu daripada perusahaan..

Dewasa ini Amerika melalui Alien Tort Claims Act (ATCA)-nya menerapkan doktrin dari kasus-kasus yang diputus oleh USMT terhadap perusahaan-perusahaan transnasional. Kasus-kasus yang diajukan ke ATCA antara lain terhadap perusahaanperusahaan German, Austria dan Amerika atau subsidiary-nya yang diuntungkan oleh slave labor selama perang dunia ke-2. Berkaitan dengan gugatan di bawah ATCA ini Pemerintah Jerman juga beberapa perusahaan Jerman setuju untuk memberikan dana kurang lebih $\$ 5.2$ billion ( $\pm \mathrm{DM}$ 10 million) untuk menyelesaikan gugatan slave labor. Data terakhir menunjukkan lebih dari 400 perusahaan Jerman menggunakan slave labor yang disediakan Nazi selama 
Tanggung Jawab Perusahaan Transnasional terhadap Pelanggaran...; Sefriani

\section{Perang Dunia II}

Kasus slave labor pertama yang diajukan di pengadilan Amerika adalah kasus gugatan terhadap pabrik mobil Amerika Ford Motor Company yang diketahui mendapat keuntungan ekonomi dari penggunaan slave labor oleh anak perusahaannya yang ada di Jerman Ford Werke A.G. Berposisi sebagai tergugat, kedua peruahaan ini dianggap had "knowingly earned enormous profits from the aggressive use of forced labor under inhuman conditions." Pengadilan mempersamakan Ford seperti natural person. Merskipun demikian pengadilan tidak dapat menjatuhkan sanksi pada Ford karena adanya treaty antara Sekutu dengan Jerman yang menyatakan bahwa tuntutan terhadap individu dan peruahaan akan diseleaikan melalui penyeleaian sengketa antar pemerintah. Treaty ini menjadi penghambat pengadilan untuk menjatuhkan sanksi pada Ford, yaitu dengan dasar nonjusticiability and international comity. .

Meskipun kasus-kasus gugatan terhadap perusahaan-perusahaan di atas mengalami kegagalan, namun hal terpenting untuk dicatat bahwa pengadilan dengan merujuk pada pengadilan Nurenberg dan USMT telah menetapkan kemungkinan meminta pertanggungjawaban pada perusahaan sebagi subyek hukum internasional disamping individu. Jelaslah bahwa legal persons memiliki kewajiban yang sama dengan natural persons dalam kasus pelanggaran HAM berat. Yang lebih penting lagi pengadilan mengakui bahwa "...TNCs, even when collaborating with a government actor, may nonetheless bear responsibility. TNCs, therefore, may be directly complicit in crimes under international law. They are not excused solely because of the presence of the state....".

\section{Membangun konsep pertanggungjawaban perusahaan transnasional}

Paparan kasus-kasus diajukannya TNC di depan pengadilan internasional pasca Perang Dunia Kedua membuktikan bahwa TNC dapat dimintai pertanggungjawaban terhadap pelanggaran HAM yang dilakukannya. Meskipun saat itu yang dihukum barulah pimpinan-pimpinan perusahaan dalam bentuk individual responsibility namun tidak berarti bahwa pengadilan internasional saat itu menyimpulkan bahwa TNC bukan subyek hukum yang dapat dimintai pertanggungjawaban. Kendala yang dihadapi pengadilan saat itu lebih pada masalah teknis keterbatasan yurisdiksi yang diamanatkan oleh instrumen pembentukan pengadilan tersebut, karena yang diajukan sebagai terdakwa bukan perusahaannya melainkan pimpinannya sebagai individu, maupun keberadaan perjanjian perdamaian antara dua negara tertentu..

Memahami konsep atau teori pertanggungjawaban perusahaan transnasional adalah tidak mudah.Tidak dapat mengabaikan doktrin-doktrin juga praktek yang berlaku mengenai pertanggungjawaban negara juga individu. Dengan demikian untuk menguji masalah pertanggungjawaban perusahaan transnasional juga harus menggunakan metode yang sama. Dari hasil penelitian yang dilakukan Ratner pada dasarnya ditemukan beberapa hambatan untuk memperluas primary rules HAM kepada perusahaan transnasional. Hambatan yang pertama menurut Ratner adalah fakta bahwa norma-norma HAM pada umumnya mengikat atau ditujukan pada negara. Kewajiban-kewajiban yang ada dalam ICCPR misalnya tidak mencakup aktifitas 
perusahaan transnasional. Hambatan kedua, adanya perbedaan sifat dan fungsi antara negara dengan perusahaan. Rejim hukum HAM menghendaki keseimbangan antara kekebasan individu dengan kepentingan negara, sehingga bila dianalogikan pada perusahaan harus ada keseimbangan antara kekebasan individu dengan kepentingan bisnis atau perusahaan.

Lebih terbatasnya ruang lingkup tanggung jawab individu membuat penerapannya secara konseptual menurut Ratner lebih mudah dibandingkan dengan penerapan primary rules tanggung jawab negara pada perusahaan. Pengakuan perusahaan sebagai juridical person atau legal person baik dalam hukum nasional maupun internasional akan mendukung gagasan memperlakukannya sama dengan natural person.,sehingga perusahaan akan bertanggung jawab terhadap kejahatan internasional yang sama seperti yang berlaku untuk individu.

Namun demikian diakui pula oleh Ratner bahwa keterbatasan ruang lingkup tanggung jawab individu itu tidak cukup untuk diterapkan pada perusahan transnasional begitu saja. Perusahaan transnasioanl menurut Ratner dapat digambarkan sebagai entity yang kurang dari negara tetapi lebih dari individu. Singkat kata dapat dikatakan adanya tantangan untuk mengkonstruksi kedua teori down from state responsibility and up from individual responsibility yang telah ada, dan akhirnya mengembangkan primary rules dan secondray rules yang baru khusus untuk menjerat perusahaan transnasional yang terlibat dalam pelanggaran HAM.

Dengan proses evolusi hukum internasional yang penuh kehati-hatian dan bertahap dapat diprediksikan bahwa dimasa yang akan datang akan terbentuk lebih banyak lagi instrumen-instrumen hukum internasional yang lebih jelas, mengikat serta dapat diterapkan langsung ada perusahaan transnasional, dibandingkan dengan yang sudah ada saat ini.. Hukum adalah agent of social policy. Rosalyn Higgins, hakim Mahkamah Internasional menekankan bahwa "[a] refusal to acknowledge political and social factors cannot keep law 'neutral', for even such a refusal is not without political and social consequence. There is no avoiding the essential relationship between law and politics." Tujuan hukum internasional adalah untuk memenuhi kebutuhan masyarakat internasional.Dengan demikian hukum internasional memerlukan adanya perubahan-perubahan. Mahkamah Internasional menegaskan sifat dinamis hukum internasional pada tahun 1949 ketika menyatakan bahwa organisasi internasional adalah subyek hukum internasional. Menurut salah satu organ utama PBB ini:

..."The subjects of law in any legal system are not necessarily identical in their nature or in the extent of their rights, and their nature depends upon the needs of the community. Throughout its history, the development of international law has been influenced by the requirements of international life, and the progressive increase in the collective activities of States has already given rise to instances of action upon the international plane by certain entities which are not States."

Christopher Weeramantry, mantan hakim Mahkamah Internasional menyatakan telah terjadi pergeseran ke arah a new legal order untuk membawa aktor transnasional ke dalam prinsip-prinsip akuntabilitas perusahaan transnasional terhadap pelanggaran-pelanggaran HAM mereka. la menekankan.

..."We must attune the international law 
Tanggung Jawab Perusahaan Transnasional terhadap Pelanggaran...; Sefriani

of the future to the concept that a large variety of new actors have appeared on the international scene, with rights and responsibilities which international law will recognize as inhering in them. The great corporations are a very important group of these new international actors whom the law of the future will recognize as accountable to the international legal system."

Meskipun demikian, mengingat mayoritas standar HAM dalam bentuk tertulis masih menempatkan negara sebagai subyek maka tidaklah selalu mudah untuk menerapkan standar tersebut pada perusahaan secara langsung. Sedikit lembaga internasional sudah menunjukkan bagaimana beberapa hak seperti right to food and housing dapat diinterpretasikan untuk diterapkan tanggung jawab sekunder pada perusahaan transnasional . Namun demikian tidak semua hak dapat diinterpretasikan dengan mudah. Beberapa hak-hak sipil dan politik seperti hak dalam pemilu, hak untuk mendapatkan peradilan yang adil, dan hakhak dimana negara dapat membatasinya dengan alasan demi kepentingan umum ( melindungi moral, law and order, serta kesehatan ) termasuk juga di dalamnya hakhak untuk menyampaikan pendapat, berorganisasi, dan menjalankan ibadat sesuai keyakinanya masih sulit untuk diterapkan langsung pada perusahaan transnasional.

Putusan decisionmaker untuk menentukan kapan perusahaan transnasional dapat dimintai pertanggungjawaban dan kapan tidak dapat adalah sangat penting. Untuk Membangun teori pertanggungjawaban perusahaan transnasioanal seputar HAM yang lebih baik dapat melihat pada persamaan dan perbedaan entityini dengan individu maupun negara. Singkat kata dapat dikatakan adanya tantangan untuk mengkonstruksi kedua teori down from state responsibility and up from individual responsibility yang telah ada, dan akhirnya mengembangkan primary rules dan secondray rules yang baru khusus untuk menjerat perusahaan transnasional. Beberapa prinsip yang ditemukan dalam primiary rules dan sceondary rules untuk negara maupun individu mengandung kemiripan yang dapat diterapkan pula terhadap perusahaan. Tetapi sekali lagi dapat dinyatakan bahwa norma-norma yang dikembangkan dalam proses pidana adalah cukup sebagai bukti untuk mengakui bahwa noncriminal forms of responsibility adalah dimungkinkan.

\section{Penutup}

Berdasarkan pemaparan tersebut dapat disimpulkan bahwa kegagalan primary rules dengan sistem indirectly obligation HI klasik telah menimbulkan suatu perkembangan baru dalam hukum internasional terhadap pengaturan pertanggungjawaban HAM perusahaan transnasional. Dewasa ini telah ada beberapa instrumen yang membebankan kewajiban langsung (direct obligaton) pada perusahaan transnasional. Beberapa instrumen yang dimaksud adalah Global Compact 2000, ILO Declaration, OECD Guidelines juga UN Norms on The Responsibilities of Transnational Corporations and Other Business Enterprises with Regard to Human Rights 2003. Meskipun demikian, primary rules dengan sistem directly obligation ini masih memliki beberapa kelemahan antara lain kurangnya sanksi dalam hal keberadaan standar HAM (kelemahan pertama), dalam hal dasar pemikaran atau prinsip-prinsip yang mendasarinya (kelemahan kedua dan ketiga), dalam hal struktur atau sistem pertanggungjawabannya (kelemahan 
UNISIA, Vol. XXX No. 65 September 2007

keempat) serta dalam hal implementasinya (kelemahan kelima), namun setidaknya, instrumen-instrumen tersebut yang merupakan soft law telah memberikan pengaruh pada proses perubahan hukum internasional atau progressive development of international law. Melalui instrumen soft law tersebut akan dapat terbentuk hukum kebiasaan internasional yang mengikat serta dapat mendukung terbentuknya kaedah baru hukum internasional yang mengikat untuk menerapkan akuntabilitas pada perusahaan transnasional atas pelanggran HAM mereka.

Pelanggaran HAM yang dilakukan TNC mencakup HAM sipil dan politik, sosial budaya juga pelanggaran hukum humaniter internasional.Dalam melakukan pelanggran TNC dapat melakukkannya secara langsung maupun tidak langsung. TNC dapat bertindak aktif sebagai perpetrator, sebagai aktor intelektual maupun hanya sebagai agent of government. TNC juga dapat dimintai pertanggungjawaban untuk kepasifannya terhadap pelanggaran HAM yang terjadi, meskipun pihak pelakunya adalah pihak lain. Perusahaan transnasional dapat dimintai pertanggungjawaban berkaitan dengan pelanggaran HAM-nya baik di tingkat pengadilan nasional maupun internasional. Kesulitan korban pelanggaran HAM perusahaan transnasional mendapatkan keadilan di negaranya sendiri menjadikan maraknya gugatan yang diajukan ke pengadilan-pengadilan di Amerika Serikat yang menyatakan dirinya memiliki yurisdiksi berdasarkan Alien Tort Claim Act (ATCA) untuk mengadili pelanggaran hukum internasional yang dilakukan baik oleh individu maupun perusahaan transnasional, meksipun tidak memiliki keterkaitan sama sekali dengan kewarganegaraan korban maupun pelaku juga tempat terjadinya pelanggaran HAM. Proses persidangan di pengadilan-pengadilan ad hoc internasional untuk pelanggaran Hukum Humaniter Internasional Pasca Perang Dunia ke-2 juga membuktikan bahwa perusahaan transnasional dianggap sebagai legal person yang dapat dimintai pertanggungjawaban atas pelanggran Hukum Humaniter Internasionalnya. Meskipun saat itu yang diajukan sebagai terdakwa hanya pimpinan-pimpinan perusahannya namun hal ini lebih disebabkan oleh kendala teknis yang dihadapi pengadilan seperti adanya perjanjian perdamaian Jepang-Amerika, yang dijukan sebagai tersangka hanya individunya, serta kendala dari instrumen pembetukan pengadilan itu sendiri yang membatasi yurisdikisinya hanya untuk individu.

Dengan dmeikian sabgat perlu kiranya pengembangan lebih lanjut konsep pertanggungjawaban pelanggaran HAM perusahaan transnasional baik di lingkup pengadilan nasional maupun internasional, mengingat masih banyaknya kelemahan yang ditemukan dalam instrumen-instrumen hukum internasional saat ini. Dalam membangun konsep pertanggungjawaban TNC di masa yang akan datang dapat dengan melakukan perbandingan dengan konsep pertanggungjawaban negara juga individu yang sudah lebih dulu exist. Disadari bahwa TNC adalah subyek yang terletak di tengah-tengah antara negara dengan individu. TNC lebih dari individu tetapi kurang dari negara.

\section{Daftar Pustaka}

Aceh:Gugatan Hukum Terhadap Exxon Mobil atas keterlibatannya dalam pelanggaran HAM di Aceh".2005. www.dte.gn.apc.org/501Ac.htm Diakses 24 Januari 2005

Andrew Clapham \& Scott Jerbi, 2001, Cat- 
Tanggung Jawab Perusahaan Transnasional terhadap Pelanggaran...; Sefriani

egories of Corporate Complicity in Human Rights Abuses, Hastings Journal of International and Comparative Law Review

Anita Ramasastry, 2002, Corporate Complicity: From Nurenberg to Rangoon an Examination of Labor Cases and Their Impact on the Liability of Multinational Corporations, Berkeley Journal of International Law,

Carlos M Vazquez,2005, Direct vs indirect obligation of corporations under international Law, Columbia Journal of Transnational Law, No 43

Carolin Hillemanns, 2003, UN Norms on the Responsibilities of Transnational Corporations and Other Business Enterprises with regard to Human Rights, German Law Journal No 10 (1 Oct 2003), European and International Law

Christina Ochoa, tt.Advancing The Language of Human Rights in a Global Economic Order: an Analysia of a Discourse,

David Weissbrod \& Muria Kruger, 2003, "Norms on The Responsibilities of transnational corporations and other business enterprises with regard to human rights", dalam American Journal of International Law, Vol.97., Oktober

David Kinley dan Sarah Joseph, 2002, "Multinational Corporations and Human Rights:Questions about their relationship", Alternative Law Journal, Vol 27 No 1 February 2002,Castan Centre for Human Rights Law, Monash University, Australia,
Dixon, Martin, 2000, Textbook on International Law, Blackstone Press Limited, fourt edition

Francois Rigaux,1991, "Transnasional Corporation", dalam Mohammed Bedjaoui (ed), International Law:Achievements and Prospects, Martinus Nijhoff Publishers, UNESCO, 1991

Frank J. GarciaTrading,1999. The Global Market and Human Rights: Away the Human Rights Principle, 25 Brook Jornal of .International Law 51.

Gabrielle Marceau, 2002, WTO Dispute Settlement and Human Rights, European Journal of International Law Vol 13.

Harvard Law School, 2001, Corporate Corporate Liability for Violations of International Human Rights Law dalam http;//www.globalpolicy.org/ intljustice/atca/2001/03crplbty.hymlabout Harvard Law Review 114 Harv. L. Rev. 2025

Huala Adolf, 2003, Hukum Ekonomi Internasional suatu pengantar, PT Raja Grafindo Persada, Jakarta, cetakan ketiga.

International Council on Human Rights Policy, 2002, Beyond Voluntarism Human Right and the Developing International Legal Obligation of Companies, Switzerlznd,

Jaringan Advokasi Tambang,2005. "PT Freeport-Rio Tinto:Lambang Kejahatan Kemanusiaan atas Papua Barat", www.jatam.org/indonesia/ case/fi/242002.htm diakses 24 
UNISIA, Vol. XXX No. 65 September 2007

Januari.

Louis Henkin, 1999, The Universal Declaration at 50 and the Challenge of Global Markets, 25 Brook, J.Int'l17, 25

Mochtar Kusumaatmadja, 1982, Pengantar Hukum Internasional, Buku I Bagian Umum, Binacpta, Jakarta, catakan keempat

Patricia Stirling, 1996, "The Use of Trade Sanctions as an Enforcement Mechanism for Basic Human Right a Proposal for Addition to the World Trade Organization ", American Journal International Law and Policy, Vol 11

Ratner,Steven R. 2001, Corporations and Human Rights: a Theory of Legal Responsibility, dalam The Yale Law Journal, Vol 11::443, Nov,28,

Sumantoro, 1984, Bunga Rampai Permasalahan Penanaman Modal dan Pasar Modal/ Problems of Investment in Equities and in Securities, Binacipta,

Surya Deva, Tt, "Human Right Violations By Multinational Corporations and International Law:Where from Here?, dalam Connecticut Journal of International Law Fall 200

Todung Mulya Lubis, 2004, "Corporate Responsibility," dalam harian Kompas, 5 Januari 2004

,2004, "Tragedi Teluk Buyat", dalam harian Media Indonesia, tanggal 9 Agustus 2004
Viljam Engstrom, 2002, Who is Responsible for Corporate Human rights Violation?,Abo Akademi University, Institute for Human Rights, January 2002, http// www.unglobalcompact. otg

WALHI,2005."Korporasi Tambang Berkontribusi terhadap Pelanggaran HAM dan Kekerasan". www.walhi. or.id/ kampanye/tambang/reformkeb/tamham=freeport 1 , diakses 24 Januari.

Wayan Parthiana, 1990, Pengantar Hukum Internasional, Mandar Maju, Bandung, hlm. 58-93

William Schabas, Tt, Enforcing humanitarian international law: Catching the accomplices, 42 Revue Internationale

Wolfgang Friedman,1972. Law in a Changing Society, $2^{\text {nd }}$ edition.

Jonathan I Charney, Tt, Transnational Corporations and Developing Public International Law, dalam Duke Law Journal No.748,

\section{Surat Kabar}

Kompas, tanggal 16 Januari 2004

Commentary on the Norms on The Responsibilities of Transnational Corporations and Other Business Enterprises with Regard to Human Rights, U.N. Doc. E/CN.4/Sub.2/2003/38/Rev.2 (2003).

Draft Responsibility of States for Internationally Wrongfull Acts 2001 
Tanggung Jawab Perusahaan Transnasional terhadap Pelanggaran...; Sefriani

The U.N Norm on the Responsibilities of Transnational Corporations and Other Business Enterprises with regard to human rights 2003, U.N Doc E/CN.4/ Sub.2/2003/12/Rev.2(2003)

\section{The Global Compact 2000}

$\square \square \square$ 